\title{
DIXDC1 wt Allele
}

National Cancer Institute

\section{Source}

National Cancer Institute. DIXDC1 wt Allele. NCI Thesaurus. Code C117256.

Human DIXDC1 wild-type allele is located in the vicinity of 11q23.1 and is approximately $95 \mathrm{~kb}$ in length. This allele, which encodes dixin protein, is involved in the Wnt signaling pathway. 